\title{
The Meaningo fmedical malpracticemintheperspective of Human Rightsin Indonesia
}

\author{
Mochammad Istiadjid Eddy Santoso ${ }^{1 *}$ Prija Djatmika ${ }^{2}$, Bambang Sugiri ${ }^{2}$, \\ Suhariningsih ${ }^{2}$ \\ ${ }^{1 *}$ Faculty of Medicine, Universitas Brawijaya, Indonesia ${ }^{2}$ Faculty of Law, Universitas Brawijaya, Indonesia
}

\begin{abstract}
:- patient to solve all their medical problems regardless of the illness, organ, ages, and genders, and as much as possible, thoroughly, completely, continuously and in coordination and collaboration with other health professionals, using the principle of effective and efficient services and uphold the professional responsibilities, legal, ethical and moral. The service is limited to the convening of basic medical competence acquired during medical education. The meaning of malpractices (error practice) of medical profession in the perspective of human rights is still unclear. This research was normative research by studying and analyzing law and health materials. Human rights are inherited rights in humans since their birth as a human being. Those rights conclude: right to life, right to health care, and the right to self-determination. Medical malpractice is the failure of the doctor to meet the standard medical treatment to the patient's disease, or a lack of skills or negligence in providing treatment for the patients, causing harm and injury to the patients. Medical malpractice may also be interpreted as any kind of wrongdoing, or negligence of doctors in treating patients which are not in line with the norms prevailing medical practices which may cause injury and/or harms to patients, even death, so as to violate the patient's human rights.
\end{abstract}

Keywords:- medical malpractice, human rights, medical law, Indonesia

\section{INTRODUCTION}

Someonelivingonthebasisofmoralprofessionmaynotworkformoney;theyfeelacallodogoodforhebenefitan dwelfareoffellowhumanbeings,especially the one whom seeks for help. To do altruisticprovisionfserviceswithotherslikethat,aprofessional will become someone respected and they shouldgainrecognitionandhonor(honor,honorarium,honoraria). A professional shall not be lowered in rank ordegradinghisowndignityobecomeahiredmanorthemeresalaryman (Mufida, 2012). The second condition that must be metistheircommandofahighqualitytechnicalexpertise that can be used to realize the virtuesverywellTheywhomcalledasaprofessionalhavetospendmostoftheirlife to attend education and training for many years exclusively in order toreachtherequiredhighskills. Suchpublicservices which are conducted haphazardly and carelessly byanyuntrainedpeoplewouldpotentiallycreateproblemsleading to an adverse event (Mufida, 2012).The third conditiontomeasurethepresence or absenceofprofessionalism is the existence of a real willingness to voluntarilybowtothecontroloftheprofessional organization, based on a set of normsofconduct(socalledethicalcodes)whicharewrittendevelopedandagreedwithin the organization. Thus, within the activities of professional workers, controlsmaygrowinordertokeepthequality of technical proficiency and ethical behavior of theprofessionalworkerswhoarealwaysinternalandautonomous (Mufida, 2012). Control over the skill and ethical conduct of a professionalmaynotevercomefromoutside, especially from the government or state and meansoflegislationenforcedbytheexecutiveandjudicialofficials. Basically, professional workers weremainlyunderthecontrolofprovisionsformulatedinasmallbookcalledlthe Ethical Code. The compliance ofthisprofessionalethicsbythemembersissupervisedbyanHonoraryBoardthatisespecially formed to enforce the enactment of the ethics (Mufida, 2012).

\section{REVIEW OF RELATED LITERATURE}

Speaking of medical science at the time of Ancient Greeks certainly cannot be separated from the figure of Hippocrates. He is an influential Greek figure and lived between the years 460-377 AD. Initially, he was a philosopher and became a doctor. Hippocrates is considered as the father of science as his teachings and writings provide rationale and scientific to medical science which previously had strong concentrated on Shamanism and religious concepts. His writings have been known as the Hippocratic Corpus (the set of writings using the name of Hippocrates).Among the important teachings of Hippocrates are:

a. A doctor is not supposed to work for personal gain, but because of love in humans. 
b. Disease should be studied with a detailed investigation, and the cases should be carefully recorded and assessed to establish a prognosis.

c. The disease is often caused by forces in the environment, food, climate and jobs.

d. A doctor must give priority to simple medical procedures, supported by careful observation and surgical intervention if necessary (Mufida, 2012).

The term "doctor" provides a number of predicates, responsibilities, and other existential roles. Without forgetting the dominant process of learning and intellectual development, a doctor is also, in principle, mandated to carry out the anthroposocial tasks and realization of individual responsibility, and also embodies the "truth" and justice, which certainly will not be separated with the context and reality of where he is. By continuing to obey the responsibility of scientific disciplines, doctor's entity shall be able to bring together the conception of medical world with the reality of today's society (Mufida, 2012).

The task of a "doctor" is covering the following matters:

a. Performing an examination on patients to diagnose the disease quickly and providing fast and precise therapy.

b. Providing therapy to cure patient's disease.

c. Actively providing medical services to patients at the time of healthy and sick.

d. Handling acute and chronic diseases.

e. Conducting medical records that meet the standards.

f. Taking early stages action of severe cases to be ready to be sent to the hospital.

g. Remain responsible for patients referred to a specialist doctor or being treated in hospital and monitor the patients who have been referred or consult to other party.

h. Acting as partners, advisors and consultants for their patients.

i. Providing advice on care and maintenance as illness prevention.

j. As the development of medical science, the current treatment to the patients should be comprehensive, covering suggestive, preventive, curative and rehabilitative services.

Doctors are also entitled and obliged to take such action for the health of the patients, namely disseminating actions such as giving lectures and preventive actions such as vaccination, curative actions such as providing medicine/surgery, and rehabilitative actions such as medical rehabilitation.

1) Fostering families of the patients to participate in the efforts to improve the level of health, disease prevention, treatment and rehabilitation.

2) Introspecting and having lifelong self-development, learning and conducting research to develop medical science.

3) The duties of the doctor are exclusive rights to provide a Certificate of Medical Statement and Record after and during the examination to the patients (Mufida, 2012).

Based on its historical review, medical world was originally seen as a very noble profession, so that with this assumption; the people who are involved in the ongoing process of life and the world of medicine later are attributed as people who also have the glory, both in word, attitude and character as it is embodied. By considering the medical profession as the work which is constantly struggling to close the doors of death and opens widely the opportunity to maintain and continue person's life, then social agreement has been constructed upon the urgency of medical science as one of the main prerequisites to sustain life (Mufida, 2012).

In the end, the medical profession becomes a major science (master of science), where each doctor is considered as a genius and knows everything, and everyone tries to be a doctor bearing the large role in this noble work. The medical profession is regarded as an art in life; not everyone can easily get the skills in medical actions, although it was just a simple medical procedure that can be owned by everyone today. With the increasing complexity of human life, then the wide scope of medical science has forced to undertake the development and improvement of quality, according to the complexity of the object of treatment encountered in reality (Mufida, 2012).Thus, the process of desecration of medicine (treatment) begins, where everyone has the opportunity to understand and have the medical sciences, as well as agreeing terms through the more systematic educational process. On the other level, the development of preexisting medical science has become an integral part, so medical research has been conducted by utilizing modern technology, to enhance the treatment of the existing knowledge (Mufida, 2012).

\section{MATERIALS AND METHOD}

Type of Research

This study used normative legal research because this research is focused on the assessment of the legal provisions (normative) that the law related to health. The approach emphasizes on normative basis that becomes 
the starting point of this research which is the analysis of the primary legal materials in the form of relevant legislation and secondary legal materials to provide solution to the issues related to the meaning of malpractice in the perspective of human rights. Legal research was conducted by reviewing the relevant literature materials or secondary data called normative legal research or literature legal research consisting of: 1) study of the principles of law; 2) study of systematic law; 3) study of the vertical and horizontal synchronization; 4) legal comparison; and 5) legal history (Soekanto, 1987).

Research Approach

Philosophical Approach

Comprehensive philosophical approach was employed to search, review and analyze the values related to the meaning of medical malpractice in the perspective of human rights and its relation to the safety, usefulness and fairness in the community.

\section{Statute Approach}

This approach was conducted to investigate several laws that form the basis for seeking the judicial aspect to the meaning of medical malpractice in the perspective of human rights, in the context of expediency and social justice.

\section{Conceptual Approach}

This approach was to examine the juridical concepts that govern the formulation of the meaning of medical malpractice in the perspective of human rights in the form of some theories, principles, rules and norms in civil liability, expediency, justice, therapeutic contract (Inspanning Theory), compensation, medical malpractice, informed consent, mediation and human rights.

\section{Historical Approach}

The historical approach was used to study about the practice and rules of law and ethics related to the medical profession from time to time.

\section{RESULTS AND DISCUSSION}

Medical Practice in the Perspective of Human Rights (HAM)Article (1) of the Declaration on Human Rights (HAM), which referred to human rights is "a set of rights attached to nature and human existence as a creature of God and that grace that must be respected, upheld and protected by the state, government and anyone for the respect and protection of human dignity". Everyone has the right to a standard of living, adequate for the health and well-being of themselves and their families as mentioned in Article (25) of the Universal Declaration of Human Rights. The State recognizes the right of everyone to the highest attainable standard that can be achieved on the physical and mental health (Hermansyah, 2010).In order to maintain public health, it requires a variety of facilities, and the existence of these facilities cannot be abandoned. Such facilities are: 1) health care institutions, such as hospitals, health centers, clinics and polyclinics, maternity hospitals, doctor's practices, midwife or nurse, and others; 2) human resources of health, such as doctors, nurses, midwives, pharmacists, pharmacist's assistants, and others; 3) health service management system; 4) health economic; 5) health technology; and 6) health policy. From all of that, it can be concluded that health or healthiness and the efforts to achieve a healthy life requires knowledge and infrastructures, and the existence of these elements and the supporting infrastructures cannot be denied. Although it is gradual, the presence of all facilities and health knowledge should be realized by observing the overall policy of the various aspects of the people's needs (Hermansyah, 2010).One of these facilities is the doctor; in other words, doctor is the "leader" in health care services. Nevertheless, the presence of other health workers whose specialty cannot be replaced is important as well. In providing health care, all doctor's behaviors should be highlighted by the Medical Law, meaning the doctor is the object of law studies, that is which rules are binding on physician behavior and which rules can be examined from various aspects of the law. In the aspect of normative law studies, it can be said that all written regulations are binding doctor's behaviors in order to carry out the legal profession can be included as a Medical Law. The study of medical law which is seen from the point of the normative law has meaning that the medical law can be examined from three perspectives, namely: 1) administrative aspect of medical law, 2) civil aspects of medical law, and 3) the criminal aspects of medical law. Those three aspects bind the behavior of doctors in their profession. Doctors must complete their behavior according to the rules so that they are not accused to do "malpractice" from the legal aspects (Hermansyah, 2010).As for the details of the rights of patients in the context of human rights is including the right to information. In the context of human rights, physicians and patients are equal and patients must get their rights, including the right to information. Those rights include that patients should be treated equally, including to obtain information on the truth of the disease and the diagnosis given by the doctors. According to the real information of the patients, the doctor will pass his/her opinions and 
views on to the patient. He/she should also inform the patients about the medical treatment plan, including how long the treatment will last and the effects needed to be anticipated, such as inconvenience that will be experienced, the nature and form of complications, and so forth. During the patient-doctor consultation, the flow of information from the patient to the doctor and vice versa, should run uninterruptedly (Badu, 2013).The regulation of the right of health in some legal instruments can be found in Article 25 verse (1) of Universal Declaration of Human Rights, that: "Everyone has the right to a standard of living adequate for health of himself and of his family, including food, clothing, housing and medical care and necessary social service". The right to health is fundamental for each individual in terms of performing other basic rights, including the achievement of an adequate standard of living. The process of universal declaration human rights are:

1. The Rights to Healthcare.

2. The Rights to Information.

3. The Rights to Self-determination (Badu, 2013).

The right to health has a broader scope, not only in regards to individual's personal matters but it includes all the related factors that contribute to healthy living of the individual, such as environmental issues, nutrition, housing, etc. While the right to health protection and the right to medical care, which is the right of the patient, are more specific sections of the right to health (Badu, 2013).

\section{Health Service as Human Rights}

"Health is a healthy condition, both physically, mentally, spiritually and socially to enable every people to live socially and be productive economically", (WHO).

Health is an important aspect of human rights, as stated in the Declaration of Human Rights of the United Nations (UN) November 10, 1948. In the Article 25, paragraph 1 of the Declaration of Human Rights states that "everyone has the right to a standard of living and adequate for the health and well-being of himself and his family". This right to health means that the government has to create conditions that allow every individual to live a healthy life, with efforts to provide adequate health care facilities and affordable health care for the society (Ramanta, 2013).Human rights are the rights inherent in humans since their birth as a human being. These rights are obtained not by giving from other people or countries, but because of his/her birth as a human being. In the religious context, this right is a gift of God, and only God has the right to revoke it (Wahid, 2013).

Because human rights are the rights acquired at birth as a human being, meaning when the rights is revoked or reduced may result in reduced degree of humanity. The measurement of the degree of humanity is always evolving in accordance with the civilization of society. It is clear that the first basic right is the right to live which brings the consequence of the other rights like the right to get living and decent works, the right to make a family and continue the offspring, the right to get citizenship and the right of expression, association and assembly. In further developments, the degree of humanity is also determined by the level of education and health; as health and education become part of human rights, all the other rights related to education and health should be fulfilled to pursue education and health (Wahid, 2013).On the other hand, the International Convention on Economic, Social and Cultural Rights established by United Nations in 1966 also recognizes the rights of everyone to enjoy the highest standards that can be achieved in the physical and mental health. As for human rights, the right to health is the inherent rights of a person because of his birth as a human being, not given from a person or country, and therefore, it cannot be revoked and violated by anyone (Wahid, 2013).

World Health Organization (WHO) defines healthy as not only free from the disease, but as a prosperous condition of the body, soul, and social to enable every person to live economically productive life. A healthy person does not experience physical complaints, but also find relief from the psychological pressure and can interact and contribute socially to the environment(Wahid, 2013).

Universal coverage can be interpreted as a guarantee of health care for the entire population. In the realization, the entire population is guaranteed to get health service access without the cost of health services obtained at that time. Health insurance does not mean free health care; health care is expensive, it is just that financing mechanisms should be managed so that each resident does not have to spend any payment to get the services. One time health care costs will be paid by a person or an institution (Wahid, 2013).

Health is a state of well-being of body, soul, and social that allows every person to be economically productive (Article 1 verse (1) of Indonesian Health Act). Therefore, health is the basis of the recognition of the degree of humanity. Without health, the person becomes conditionally unequal. Without health, a person would not be able to acquire the other rights. Someone who is not healthy will have their rights to live diminished, he may not be able to obtain and undergo a proper job, enjoy the rights to form association and assembly and express their opinions, and obtain education for the sake of his/her future. In short, someone cannot fully enjoy life as a human being if he has health problem (Wahid, 2013).

The importance of health as a human right and as a necessary condition for the fulfillment of the other rights has been recognized internationally. The rights to health include the right to get a healthy life and work, 
the right to get health care and special attention to maternal and child health. Article 25 of the Universal Declaration of Human Rights (UDHR) states:

1. Everyone has the right to an adequate standard of living for the health and well-being of himself and of his family, including food, clothing, housing, and medical care and social services, and the right to security in the event of unemployment, sickness, disability, widowhood, old age or other lack of livelihood in circumstances beyond his control.

2. Motherhood and childhood are entitled to special care and assistance. All children, whether born under or out of wedlock, shall enjoy the same social protection (Sudrajat, 2011).

The importance of health and human rights context are also listed in the preamble of Indonesia's Act number 36 of 2009 on Health, which is written as follows:

a. That health is a human right and one of the elements of well-being that must be realized in accordance with the ideals of the nation of Indonesia as referred in Pancasila (five principles of noble values in Indonesia) and the Constitution of the Republic of Indonesia 1945;

b. That any activity in effort to maintain and improve the health of communities as high as possible should be implemented by the principles of non-discriminatory, participatory, and sustainable in the context of the formation of human resources in Indonesia, as well as increasing resilience and competitiveness of the nation for national development;

c. That any factors that may cause public health problems in Indonesia would cause huge economic losses for the country, and every effort should be taken to improve community health status also means investment for the country's development;

d. That every development effort must be based on the insight of health in terms of national development and should pay attention to public health which is the responsibility of all parties, both government and the public

Based on some information in some countries, from the perspective of human rights, the meaning of medical malpractice can be summarized as follows:

1. Both in countries with Anglo-Saxon legal system (Common Law) or Continental legal system (Civil Law) there are similarities in defining medical malpractice. The meaning of "medical malpractice" is an error, negligence, deviation from professional standards, standard procedures and norms of medical practice prevailing in treating patients, incompetent or omission committed by doctors, who may cause harm, injury, illness, and disability or even death to the patients.

2. Injuries which are caused by negligence is described as "an incident, even though it was accidental, caused by the negligence, carelessness, unskilled, or failure to comply with laws, regulations, order and discipline of the medical profession".

\section{The Meaning of Medical Malpractice}

To discuss the meaning of medical malpractice, firstly, we have to learn some of the provisions of international law. Black's Law Dictionary defines malpractice as:

"professional misconduct or unreasonable lack of skill" or "failure of one rendering professional services to exercise that degree of skill and learning commonly applied under all the circumstances in the community by the average prudent reputable member of the profession with the result of injury, loss or damage to the recipient of those services or to those entitled to rely upon them" (Garner, 2004:89).In daily communication, what being accused is medical malpractice which is the term of some of professional misconduct by doctor which results in injury, death or loss to the patients. Purwadarminta (2003) defines malpractice (mala praktik) as "medical practice which is wrong, improper, violate any law or code of conduct" (p.711).

Professional misconduct which is deliberate action can be done the form of violation of ethics, provision of professional discipline, administrative law, as well as criminal and civil law, like doing intentional act which cause harm to the patients, "containment" of the patient, the violation of medical confidential, illegal abortion, euthanasia, sexual abuse, misrepresentation or fraud, perjury, using untested/unaccepted science and medical technology, performing medical practice without license and outside his/her competence and so on. Those deliberate actions do not have to be intentional action resulting bad outcomes for patients, but the important thing is pointing to deliberate violation (related to motivation, in the form of violence) rather than just the form of error (in relation to the information provided) (American College of Legal Medicine, 1991:525).

Negligence may occur in three forms, which are malfeasance, misfeasance and nonfeasance. Malfeasance means doing an unlawful or improper act (unlawful or improper), for example, performing medical acts without adequate indications. Misfeasance means choosing proper medical action but performed improperly (improper performance), for example, performing medical acts in violation of the procedure. Nonfeasance is not conducting medical action which is part of the obligation for the doctors. The forms of negligence above is on the same line with the form of error (mistake), but the omission must meet all four elements of negligence in law, particularly the existence of loss, while the error does not always result in losses, so does the presence of latent 
errors that do not directly cause adverse effects (American College of Legal Medicine, 1991:510).Medical negligence is a form of medical malpractice, as well as a form of medical malpractice that occurs most frequently. Basically negligence occurs when a person unintentionally does something (commission) which should not be done or not do anything (omission) that is supposed to be done by others who have the same qualifications in the same condition and situation. In general, negligence committed by an individual is not an act that is punishable, unless it is done by someone who is not supposed to be (based on the nature of the profession), or people who should do it but act carelessly and such actions have resulted in harm or injury to others.

An act or attitude of doctors is considered negligent if it meets the following four elements, namely (American College of Legal Medicine:1991):

a. Duty or obligation of doctors to perform or not to perform a specific action toward certain patients in certain circumstances;

b. Dereliction of the duty

c. Damage or loss that is everything perceived by the patient as a loss of health care provided by the service providers.

d. Direct causal relationship. In this case there must be a causal connection between deviations liabilities and losses that at least is a "proximate cause".

World Medical Association (WMA) also reminds that not all failures are the result of medical malpractice by doctors. An adverse event that was unforeseeable that occurs when a standard medical action is performed but result in injury to the patient is not included in the definition of medical negligence malpractice.

"An injury occurring in the course of medical treatment which could not be foreseen and was not the result of the lack of skill or knowledge on the part of the treating physician is untoward result, for which the physician should not bear any liability" (American College of Legal Medicine, 1991:258).

Thus, an unforeseeable negative consequence in the perspective of science and medical technology at the time and under the circumstances and available facilities is not imposed to the doctor's liability. That is, adverse events (unexpected outcomes) may occur as the result of the absence of errors/omissions and may also be caused by errors/omissions. Adverse events due to errors/omissions are considered preventable. If the preventable adverse event has caused a loss, it meets all the elements of medical negligence according to the law, so it is called negligent adverse event.

An adverse event in the medical field can actually be attributed to several possible reasons:

a. Result from the disease itself, not related to the medical action conducted by the doctor.

b. The result of a risk that cannot be avoided, the risk that cannot be known in advance (unforeseeable); or risk which had known before (foreseeable) but cannot be avoided (unavoidable), due to medical acts performed are the only means of therapy. These risks should be informed in advance.

c. Result of a medical negligence.

d. Result of deliberate actions.

In connection with these risks, any medical actions may carry risks, so a preventive action or risk-reducing action must be done. However, most of them still can be done because the risk is acceptable in accordance with "state-of-the-art" science and medical technology. Acceptable risks are included as follows:

a. Risks with quite small degrees of probability and severity can be anticipated, calculated or can be controlled, such as drug side effects, bleeding and infection at the surgery, and others.

b. The risk with large degree of probability and severity in certain circumstances, when that risky medical action has to be done because it is the only way to be taken, especially during emergency (American College of Legal Medicine, 1991:21).

The terms "medical malpractice" which is directly on clinical cases with the unwanted outcome is incorrect or unfair. The actual neutral terms before the evidence proofing is clinical adverse incident, adverse event, or medical accident, which are commonly used in the British literature (in American literature is more frequently used words as medical error since the early, which is also not neutral). Adverse clinical incident or medical accident describe a clinical event that does not fit or is contrary to expectation, without establishing first what the cause of that undesirable event and who is to blame. This is appropriate with the legal principle of presumption of innocence until the fault is really proven.To reduce adverse events (undesirable incident) and medical negligence can be done through clinical risk management. Clinical risk management is a process that systematically identifies, evaluates and directs such events that are potentially risky through restructuring program to prevent, control and minimize any potential risks (American College of Legal Medicine: 1991:516).From the legal standpoint, in the definition of medical malpractice is as any medical practice which is performed by the doctors that is wrong, improper, violating the laws and codes of conduct, may get an understanding that malpractice may occur because of a deliberate medical action (intentional) as a certain deviation (misconduct), unwarranted negligence, lack of skill and incompetent. Thus, the legal sanctions 
against medical malpractice are not only criminal and civil sanctions, but also an administrative sanction. In addition to legal sanctions, there are also ethical and disciplinary sanctions which can be complementary elements or enhancer elements of the law.

\section{CONCLUSION}

Medical malpractice is the failure of a doctor to meet the standards of competency, the standards of the medical profession, and standard of operating procedures in the treatment of the patient's illness, lack of skills, or negligence in providing treatment for the patients, which may cause harm, injury, or death to the patientsFrom the legal standpoint, in the definition of medical malpractice is as any medical practice which is performed by the doctors that is wrong, improper, violating the laws and codes of conduct, may get an understanding that malpractice may occur because of a deliberate medical action (intentional) as a certain deviation (misconduct), unwarranted negligence, lack of skill and incompetent. Thus, the legal sanctions against medical malpractice are not only criminal and civil sanctions, but also an administrative sanction. In addition to legal sanctions, there are also ethical and disciplinary sanctions which can be complementary elements or enhancer elements of the law.

In its implementation, medical malpractice could be:

a. Performing the action that should not be done by a doctor;

b. Not performing his duty;

c. Violating a provision based on the relevant Regulation.

\section{REFERENCES}

[1] American College of Legal Medicine. 1991. Legal Medicine, Legal Dynamics and Medical Encounter, 2nd ed. USA: Mosby Year Book.

[2] Badu, L. 2013. Euthanasia dan HAM. Retrieved from download.portalgaruda.org /article.php?article= 40595\&val=5585, on November 2016.

[3] Garner, B.A. (ed.). 2004. Black's Law Dictionary, 8th ed. USA: Minn. St. Paul.

[4] Hermansyah. 2010. Perlindungan Hukum terhadap dokter dalam menjalankan profesi kedokteran dalam perspektif undang-undang nomor 29 tahun 2004 tentang praktik kedokteran. Retrieved from http://royhermansyah.blogspot.co.id/2010/08/perlindungan-hukum-terhadap-dokter.html, on November 2016.

[5] Mufida, W.A. 2012. Pengertian Dokter dan Tugas Dokter. Retrieved from http://w-afif-mufidafk12.web.unair.ac.id/artikel_detail-68894-1\%20Etika\%20Kedokteran-

Pengertian\%20Dokter\%20Dan\%20Tugas\%20Dokter.html, on November 2016.

[6] Purwadarminta,W.J.S.2003.KamusUmumBahasaIndonesia.Jakarta:BalaiPustakaRamanta,D.2013.Keseha tanMerupakanHakAsasiManusia.Retrievedfromhttps://dedyramanta.wordpress.com/2013/04/29/kesehata n-merupakan-hak-asasi-manusia/, on November 2016.

[7] Soekanto, S. 1987. Pengantar Penelitian Hukum. Jakarta: UI Press.

[8] Sudrajat,J.2011.MewujudkanHAMdiBidangKesehatan.Retrievedfromhttp://www.bumn.go.id/biofarma/be rita/2943/MEWUJUDKAN.HAM.DI.BIDANG.KESEHATAN, on November 2016.

[9] Wahid,S.2013.KesehatansebagaiHakAsasiManusia.Retrievedfromhttp://makalahplus.blogspot.co.id/2013 /08/kesehatan-sebagai-hak-asasi-manusia.html, on November 2016.

[10] Ramanta,D.2013.KesehatanMerupakanHakAsasiManusia.Retrievedromhttps://dedyramanta.wordpress.co m/2013/04/29/kesehatan-merupakan-hak-asasi-manusia/, on November 2016.

[11] Soekanto, S. 1987. Pengantar Penelitian Hukum. Jakarta: UI Press.

[12] Sudrajat,J.2011.MewujudkanHAMdiBidangKesehatan.Retrievedfromhttp://www.bumn.go.id/biofarma/be rita/2943/MEWUJUDKAN.HAM.DI.BIDANG.KESEHATAN, on November 2016.

[13] WahidS.2013.KesehatansebagaiHakAsasiManusia.Retrievedfromhttp://makalahplus.blogspot.co.id/2013/ 08/kesehatan-sebagai-hak-asasi-manusia.html, on November 2016. 